\title{
Strategies of Onion Farmers in dealing with the Effects of Army worms in their Crops
}

\author{
Denisse Kim Donato Arahan, Rollyn Joy Sebastian Bayudan Rinah Mae \\ Elaveña Dela Peña, Maria Camille de Lara Lopez, Felipe Balaria
}

\begin{abstract}
This study aimed to describe the strategies of farmers in dealing with the effects of the infestation of armyworms in their onions. It is visibly shown that when the time armyworm has started infesting the crop there's a drastic decreased in production and causing the declined of onion bags harvested. Farmers harvested only 15 bags of red onion bulbs, after planting a can of seeds that should have produced at least 50 "buriki" bags. The years 2014 and 2015 were not affected by armyworm however; there are typhoons that hit some areas in Nueva Ecija which also cause to decline the onion production. The farmers experienced a great amount of loss during armyworm infestation and cost them to lose trillions of pesos it also doubled the cost of the farmer's inputs. According to the farmers interviewed, during the normal condition, they only spend money ranging from 80,000 to 100,000 worth of inputs per hectare. Spraying of pesticides during the armyworm infestation is the most commonly used method with 305 out of 310 respondents using this method. Field monitoring and some form of scouting were also used to check the types and densities of pests present. The use of pesticides is the major solution when it comes to armyworm infestation this is basically because most of the farmers use the type of pest management method that is easy to use such as pesticides. The importance of pest control management during the attack of armyworm is necessary. However, the use of pesticide and other chemical use needs to be very carefully considered since armyworm caterpillars hide deep in the crop foliage and it is difficult to control, also such pesticides can harm natural enemies and farmers' health. This study hopes that the farmer may be able to reduce the occurrence of pests and diseases by using a more applicable Pest Management control method and thus raise production levels, lessen production cost and maximize profits.
\end{abstract}

Keywords—armyworm infestation, farmers, onion, pesticide, pest management control.

\section{INTRODUCTION}

An onion can make people cry but there's never been a vegetable that can make people laugh. "Onion, also known as the bulb onion or common onion, is a vegetable that is the most widely cultivated species of the genus Allium and its close relatives include the garlic, leek, chive, and Chinese onion" [1]. This study was undertaken to evaluate the effect of armyworm to the Nueva Ecija Farmers, so as to suggest solutions that will be helpful for the farmers. Traditionally, farmers in the Philippines can only harvest onions once a year. Those who planted sometime in the month of November last year will be harvesting the crop by the month of April since the hybrid onions mature earlier compare to the traditional varieties. "During the year 2010, a massive infestation of armyworm was reported attacking different crops: ampalaya, eggplant, okra, patola, sitao, radish, squash, tomato, upo, peanut, taro, watermelon, sweet potato, sugarcane, cassava, papaya, lanzones, calamansi, banana and lemongrass. Recorded infestations were from Regions 1
(Pangasinan), 3 (Bataan), 4A (Cavite and Batangas), 5 (Albay and Masbate) and 9 (Zamboanga del Norte)" [2]. The outbreak is suspected to have resulted from mass longdistance migration from countries northeast of the Philippines which could have been triggered after a long drought period, El Niño. Nueva Ecija was not included and onion was not listed in the affected crops in that reported 2010 infestation. However during the first quarter of 2016, onion farmers in Nueva Ecija experienced massive loss in production due to an unprecedented armyworm outbreak, report of infestation of onion reached Bureau of Plant Industry (BPI) last March 11, 2016 in Sto. Domingo, Nueva Ecija affecting five barangays. "Onion production in Nueva Ecija province, which supplies 54 percent of the country's annual output, has been reduced by almost half due to armyworm infestations that may force the government to import to stabilize supply and prices. According to Gregorio Quiñones" [3], coordinator of Nueva Ecija agriculture office, the rate of devastation by armyworms on onion farms is from 
40 to 45 percent, because destruction can happen almost overnight, the first stages of a caterpillar's life require very little food, and the later stages require about 50 times more high-value crops (Inquirer.Net) The economic impact to onion farmers was huge that it gained media and political attention and immediate action was done through the Department of Agriculture through the Regional Crop Protection Center III organized a forum in Nueva Ecija on armyworm management with entomologists from the National Crop Protection Center - University of the Philippines Los Baños as lead lecturers [4]. This forum was well-attended by local government units, agriculture officers/technicians, farmers and private companies involved in the onion industry and the highlight of the forum was a consensus from various stakeholders of the need to have an updated reference material to be used in region-wide farmer education campaign on armyworm integrated pest management (IPM) [5]. Actual field validation was undertaken. The extent of infestation of armyworm on onion, notes on its biology and possible cause of its outbreak in 2016 in Nueva Ecija were determined through site visits, interviews and dialogue with farmers, and review of pertinent literature. The species of armyworm that went into the outbreak was identified as Spodoptera exigua. A total of 14 municipalities covering 5330 ha and involved 4089 farmers were affected. An estimated total loss of PhP 1, 360, 606,492 incurred from February to April 2016. The onion capital of the Philippines, Bongabon, suffered the most loss at 2,938 hectares (OPA,2016). In line with this, the researchers conducted this study which is entitled "Evaluation On The Effects Of Army Worms To The Nueva Ecija Onion Farmers And Their Strategies To Cope With The Situation" was conducted to help us understand the effects of armyworm in the onion industry and to the farmers as well.

\section{METHODOLOGY}

The researcher used convenience sampling [6] because it is the easiest method of sampling since participants are selected based on availability and willingness to take part. Useful results can be obtained since not all farmers are available all the time. This type of sampling can be done by simply creating a questionnaire and distributing it to the targeted group. The researcher used the multiple-choice type of questionnaire. It was used to easily compile and analyze results. The researchers collected the information from the farmers from the selected municipalities in Nueva Ecija affected by armyworms.

\section{RESULTS AND DISCUSSION}

The common variety of onion produce in Nueva Ecija is the red creole. Red Creole is a medium maturing, openpollinated short day red onion. Red Creole is well adapted and very widely planted. The outer scale is dark red; the rings are tight and red right through to the center of the bulb [7]. The type of pest infesting the onions in Nueva Ecija is armyworm which is the most common pest during onion production. The effect of armyworm on the onion production in Nueva Ecija is very alarming. Yearly it outlays billions of loss to the onion farmers. During the evaluation on the effect of armyworms to the farmers, it is recorded that there are other factors incurring a great loss when it comes to the production of onion, such as the cost of spending too much from the use of pesticides, farmers also tends to harvest the onions planted ahead of time even it is not yet the best time to harvest the onion just to save from armyworm attack which leads from being sold at a low price. The researchers were also able to learn that most of the farmers have limited knowledge on how to control pest infestation and only use the pest control management method suggested by their co farmers. There is other pest control management that is available and presented by the Agricultural Department of the Philippines which is less expensive yet more helpful and safer rather than using pesticides that have health and environmental consequences.

Table 1 shows the onion industry in Nueva Ecija from 20142018 and their respective production output per metric ton (MT). It can be seen that there's a vast decrease in onion production as the years goes by from 2014 to 2018 . Bongabon has the largest area producing onion in Nueva Ecija was also the municipality with the most destruction caused by armyworm in 2016. According to the Agricultural Department of Nueva Ecija, the sudden decrease in onion production during those years is caused by the armyworm infestation. In 2017, there's an expansion in onion production, this was traced to the increases in some harvested areas as a result of the seed distribution program of the government. However, the production of onion was down by 14.47 percent in 2018 because there was shifting of some areas from onion to palay to stop the recurrence of armyworm. Likewise, smaller tubers were harvested due to early harvesting to control the damage of armyworms. 
Table 1. Onion Production in Nueva Ecija (2014-2018)

\begin{tabular}{|c|c|c|c|c|c|}
\hline \multirow{2}{*}{ Municipalities } & 2014 & 2015 & 2016 & 2017 & 2018 \\
\hline & Production (MT) & Production (MT) & Production (MT) & Production (MT) & Production (MT) \\
\hline Aliaga & 940.16 & $2,548.00$ & 20.16 & $1,307.10$ & $1,390.69$ \\
\hline Bongabon & $69,642.60$ & $27,024.50$ & $7,770.55$ & $30,051.83$ & $11,158.93$ \\
\hline Cabanatuan & 24.96 & & & & 25.64 \\
\hline Carranglan & 183.95 & 229.25 & 357.32 & 893.11 & $1,492.18$ \\
\hline Cuyapo & $2,179.00$ & $1,338.15$ & 498.90 & 897.04 & 692.70 \\
\hline Gabaldon & $14,911.97$ & $7,157.25$ & $5,079.59$ & $7,840.34$ & $8,984.84$ \\
\hline Gapan & & & & 73.36 & 34.52 \\
\hline Gen. Natividad & $1,265.50$ & $1,090.77$ & 18.48 & $1,512.43$ & $3,541.91$ \\
\hline \begin{tabular}{|l|} 
Gen. Tinio \\
\end{tabular} & 61.61 & 46.20 & 22.07 & 25.20 & 139.50 \\
\hline Guimba & $4,639.95$ & $3,034.65$ & $1,398.91$ & $3,640.87$ & $1,011.04$ \\
\hline Laur & $9,148.02$ & $4,983.86$ & $1,677.09$ & $7,471.91$ & $3,298.98$ \\
\hline Licab & 61.75 & 23.20 & 44.00 & 6.60 & 12.75 \\
\hline Llanera & $1,640.16$ & $1,851.40$ & 746.00 & $2,036.70$ & 927.57 \\
\hline Lupao & $6,010.00$ & $4,950.00$ & $5,140.00$ & $9,093.58$ & $3,997.64$ \\
\hline Nampicuan & 797.19 & 452.92 & 198.99 & 98.52 & \\
\hline Palayan City & $2,217.38$ & $3,579.52$ & 233.86 & $2,897.02$ & $1,419.95$ \\
\hline Pantabangan & $3,792.57$ & $5,529.22$ & $1,777.30$ & $1,551.32$ & $2,617.92$ \\
\hline Quezon & 733.05 & $1,767.78$ & 449.82 & $1,135.38$ & 847.30 \\
\hline Rizal & $15,541.00$ & $10,168.10$ & 326.10 & $14,072.52$ & $5,006.48$ \\
\hline San Isidro & 110.35 & 87.10 & 101.25 & 102.67 & \\
\hline San Jose City & $12,870.52$ & $9,337.94$ & $4,457.72$ & $14,960.84$ & $2,602.45$ \\
\hline San Leonardo & 47.25 & 45.82 & & 8.31 & \\
\hline Science City of Muñoz & $1,157.59$ & $1,011.88$ & 352.70 & $1,470.50$ & $1,198.80$ \\
\hline \multicolumn{6}{|l|}{ Sta Rosa } \\
\hline Sto. Domingo & $5,692.62$ & $6,293.90$ & 358.30 & $4,028.43$ & $5,167.24$ \\
\hline Talavera & $4,960.05$ & $5,393.58$ & $1,651.20$ & $5,426.17$ & $5,174.70$ \\
\hline Zaragosa & & & & 2.43 & \\
\hline TOTAL & $158,629.20$ & $97,944.97$ & $32,680.31$ & $110,604.17$ & $60,743.74$ \\
\hline
\end{tabular}

*Source: Provincial Agriculture Office of Nueva Ecija, 2018

Table 2 shows the number of onion bags produced in Nueva Ecija from the year 2014-218, it is visibly shown that when the time armyworm has started infesting the crop there's a drastic decreased in production. As early as February 2016, armyworms started to attack and causing the declined of onion bags harvested. But in the year 2017, it is shown that there's a great increase of production and the Philippines may no longer have to import onion as the Government's latest assessment indicated that there would be a surplus in output this year according to BPI. This is the result of a seed distribution program of the government according to PSA[8]. The years 2014 and 2015 were not affected by armyworm however; there are typhoons that hit some areas in Nueva Ecija which also cause to decline the onion production. 
Table 2. Total Number of onion bags produced in Nueva Ecija (2014-2018)

\begin{tabular}{|c|c|c|c|c|c|}
\hline \multirow{2}{*}{ Municipalities } & 2014 & 2015 & 2016 & 2017 & 2018 \\
\hline & Number of bags & Number of bags & Number of bags & Number of bags & Number of bags \\
\hline Aliaga & $37,606.40$ & $101,920.00$ & 806.40 & $52,284.00$ & $5,576.00$ \\
\hline Bongabon & $2,785,704.00$ & $1,080,979.80$ & $310,822.00$ & $1,202,073.20$ & $64,075.20$ \\
\hline Cabanatuan & 998.20 & & & & 204.00 \\
\hline Carranglan & $7,358.00$ & $9,170.00$ & $14,292.80$ & $35,724.40$ & $4,768.00$ \\
\hline Cuyapo & $87,160.00$ & $53,526.00$ & $19,956.00$ & $35,881.49$ & $4,540.80$ \\
\hline Gabaldon & $596,478.90$ & $286,289.80$ & $203,183.64$ & $313,613.60$ & $47,198.56$ \\
\hline Gapan & & & & $2,934.20$ & 164.00 \\
\hline Gen. Natividad & $50,620.00$ & $43,630.80$ & 739.20 & $60,497.28$ & $10,532.00$ \\
\hline \begin{tabular}{|l|} 
Gen. Tinio \\
\end{tabular} & $2,464.56$ & $1,848.00$ & 882.80 & $1,008.00$ & 400.00 \\
\hline Guimba & $185,598.00$ & $121,386.00$ & $55,956.40$ & $145,634.80$ & $7,542.00$ \\
\hline Laur & $365,920.80$ & $199,354.20$ & $67,083.60$ & $298,876.40$ & $17,484.00$ \\
\hline Licab & $2,470.00$ & 928.00 & $1,760.00$ & $929,280.00$ & 100.00 \\
\hline Llanera & $65,606.40$ & $74,056.00$ & $29,840.00$ & $81,468.00$ & $4,386.00$ \\
\hline Lupao & $240,400.00$ & $198,000.00$ & $205,600.00$ & $363,743.20$ & $11,580.00$ \\
\hline Nampicuan & $31,887.56$ & $18,116.80$ & $7,959.60$ & $3,940.80$ & \\
\hline Palayan City & $88,695.20$ & $143,180.80$ & $9,354.40$ & $115,880.80$ & $8,645.60$ \\
\hline Pantabangan & $151,702.89$ & $221,168.88$ & $71,092.00$ & $62,052.80$ & $13,534.00$ \\
\hline Quezon & $29,322.00$ & $70,711.20$ & $17,992.80$ & $45,415.20$ & $3,344.00$ \\
\hline Rizal & $621,640.00$ & $406,724.00$ & $13,044.00$ & $562,900.80$ & $38,070.00$ \\
\hline San Isidro & $4,414.00$ & $3,484.00$ & $4,050.00$ & $4,106.80$ & \\
\hline San Jose City & $514,820.77$ & $373,517.40$ & $178,308.80$ & $598,433.46$ & $35,471.60$ \\
\hline San Leonardo & $1,890.00$ & $1,832.60$ & & 332.40 & \\
\hline Science City of Muñoz & $46,303.60$ & $40,475.20$ & $14,108.00$ & $58,820.00$ & $4,432.00$ \\
\hline \multicolumn{6}{|l|}{ Sta Rosa } \\
\hline Sto. Domingo & $227,704.80$ & $251,756.00$ & $14,332.00$ & $161,137.20$ & $15,589.60$ \\
\hline Talavera & $198,402.00$ & $215,743.20$ & $66,048.00$ & $217,046.96$ & $17,043.20$ \\
\hline \multicolumn{6}{|l|}{ Zaragosa } \\
\hline TOTAL & $6,345,168.08$ & $3,917,798.68$ & $1,307,212.44$ & $5,353,085.78$ & $314,680.56$ \\
\hline
\end{tabular}

*Source: Provincial Agriculture Office of Nueva Ecija, 2018

Table 3. Total losses of Municipalities affected by Armyworm (2016-2018)

\begin{tabular}{|c|c|c|c|c|c|c|c|c|c|c|c|}
\hline \multirow{2}{*}{\multicolumn{2}{|c|}{$\begin{array}{l}\text { MUNICIPALITIE } \\
\text { S }\end{array}$}} & \multicolumn{2}{|c|}{2014} & \multicolumn{2}{|c|}{2015} & \multicolumn{2}{|r|}{2016} & \multicolumn{2}{|c|}{2017} & \multicolumn{2}{|c|}{2018} \\
\hline & & $\begin{array}{c}\text { Area } \\
\text { affecte } \\
\text { d (ha) }\end{array}$ & $\begin{array}{c}\text { Total } \\
\text { Losse } \\
\text { s (P) }\end{array}$ & $\begin{array}{c}\text { Total } \\
\text { Losse } \\
\text { s (P) }\end{array}$ & $\begin{array}{c}\text { Total } \\
\text { Losse } \\
\text { s (P) }\end{array}$ & $\begin{array}{c}\text { Area } \\
\text { affecte } \\
\text { d (ha) }\end{array}$ & Total Losses (P) & $\begin{array}{c}\text { Area } \\
\text { affected } \\
\text { (ha) }\end{array}$ & $\begin{array}{c}\text { Total Losses } \\
\text { (P) }\end{array}$ & $\begin{array}{c}\text { Area } \\
\text { affected } \\
\text { (ha) }\end{array}$ & $\begin{array}{c}\text { Total Losses } \\
\text { (P) }\end{array}$ \\
\hline 1 & Aliaga & - & - & - & - & 6.8 & $\mathrm{P} 1,550,400.00$ & 60.95 & $\mathrm{P} 1,810,215.00$ & 13.5 & $\mathrm{P} 1,023,435.00$ \\
\hline 2 & Bongabon & - & - & - & - & 2899.98 & $\begin{array}{c}\mathrm{P} 1,002,432,096.0 \\
0\end{array}$ & 36 & $\mathrm{P} 2,137,500.00$ & 409.82 & P87,360,984.00 \\
\hline 3 & Carranglan & - & - & - & - & - & - & - & - & 0.4 & Р20,520.00 \\
\hline 4 & Cuyapo & - & - & - & - & 29.69 & $\mathrm{P} 9,431,220.00$ & - & - & 2.62 & $\mathrm{P} 471,600.00$ \\
\hline 5 & Gapan & - & - & - & - & 1 & Р228,000.00 & - & - & 2.5 & $\mathrm{P} 486,000.00$ \\
\hline 6 & $\begin{array}{l}\text { Gen. } \\
\text { Natividad }\end{array}$ & - & - & - & - & 89.5 & P16,324,800.00 & 67 & P1,989,900.00 & - & - \\
\hline 7 & Guimba & - & - & - & - & - & - & 1.55 & P46,035.00 & 38.77 & Р5,824,602.00 \\
\hline 8 & Laur & - & - & - & - & 96.25 & Р26,334,000.00 & 5.7 & P16,990.00 & 16.05 & $\mathrm{P} 2,470,095.00$ \\
\hline
\end{tabular}




\begin{tabular}{|c|c|c|c|c|c|c|c|c|c|c|c|}
\hline 10 & Llanera & - & - & - & - & 32.4 & Р8,745,000.00 & - & - & 35 & Р8,977,500.00 \\
\hline 11 & Lupao & - & - & - & - & - & - & - & - & 32.45 & $\mathrm{P} 2,663,496.00$ \\
\hline 12 & Munoz & - & - & - & - & 12 & $\mathrm{P} 1,668,960.00$ & - & - & - & - \\
\hline 13 & Palayan City & - & - & - & - & 163.3 & Р22,339,440.00 & 97.7 & P6,278,580.00 & 25.2 & $\mathrm{P} 1,939,140.00$ \\
\hline 14 & Pantabangan & - & - & - & - & - & - & - & - & 3.5 & Р269,325.00 \\
\hline 15 & Quezon & - & - & - & - & 46.5 & P10,602,000.00 & 16.5 & P735,705.00 & 75 & $\mathrm{P} 1,923,750.00$ \\
\hline 16 & Rizal & - & - & - & - & 687.65 & P31,356,400.00 & 4.25 & Р336,600.00 & 13.5 & $\mathrm{P} 4,847,850.00$ \\
\hline 17 & San Jose City & - & - & - & - & 78.17 & P14,258,208.00 & - & - & 854.35 & $\begin{array}{c}\text { P153,398,542.5 } \\
0\end{array}$ \\
\hline 18 & $\begin{array}{l}\text { San } \\
\text { Leonardo }\end{array}$ & - & - & - & - & 1 & Р456,000.00 & - & - & - & - \\
\hline 19 & $\begin{array}{l}\text { Santo } \\
\text { Domingo }\end{array}$ & - & - & - & - & 427.05 & $\mathrm{P} 194,734,800.00$ & 199 & $\begin{array}{c}\mathrm{P} 21,223,620.0 \\
0\end{array}$ & 23.87 & $\mathrm{P} 1,029,681.00$ \\
\hline 20 & $\begin{array}{l}\text { Science City } \\
\text { of Muñoz }\end{array}$ & - & - & - & - & 12.2 & P1,668,960.00 & 25.1 & $\mathrm{P} 2,243,610.00$ & 29 & $\mathrm{P} 2,975,400.00$ \\
\hline 21 & Talavera & - & - & - & - & 178.19 & P18,476,208.00 & 180.55 & $\begin{array}{c}\text { P15,694,608.0 } \\
0\end{array}$ & 6.6 & P677,160.00 \\
\hline & TOTAL & & & & & 4761.68 & $\begin{array}{c}\text { P1,360,606,492.0 } \\
0\end{array}$ & 694.3 & $\begin{array}{c}\text { P52,513,363.0 } \\
0\end{array}$ & 1582.13 & $\begin{array}{c}\text { P276,359,080.5 } \\
0\end{array}$ \\
\hline
\end{tabular}

*Source: Provincial Agriculture Office of Nueva Ecija, 2018

The record of total losses of the affected area from 20162018 was gathered and provided by the Nueva Ecija Provincial Agricultural Office. The PAO states that the outbreaks started in 2016 which was triggered by El Niño. The table shows the pest infestation during the last three years (2016-2018), the area planted (ha) and the total losses (P) per municipality. It can be seen that there is a great loss during the time of armyworm outbreak by the year 2016 around the month of February which was the first time that the said pests attack the onion field in Nueva Ecija, especially in the municipality of Sto. Domingo and Bongabon, which incur billion of losses. The pest infestation has doubled the cost of the farmer's inputs. According to the farmers interviewed, during the normal condition, they spend money ranging from 80,000 to 100,000 worth of inputs per hectare. According to Ariel Alejo[8], crop protection officer of the Nueva Ecija agriculture office, farmers harvested only 15 bags of red onion bulbs, after planting a can of seeds that should have produced at least 50 bags, and fail to generate 50 'buriki' (bags) per can and cause the farmers to lose profits.

Table 4. Cost in Producing Onion (Red Creole) during Armyworm attack

\begin{tabular}{|c|c|c|c|c|}
\hline \multirow{2}{*}{$\begin{array}{c}\text { Cost per hectare } \\
\text { (Php) }\end{array}$} & \multicolumn{4}{|c|}{ Municipalities } \\
\hline & $\begin{array}{c}\text { Bongabon } \\
\text { (180 respondents) }\end{array}$ & $\begin{array}{c}\text { Rizal } \\
\text { (110 respondents) }\end{array}$ & $\begin{array}{c}\text { Natividad } \\
\text { (14 respondents) }\end{array}$ & $\begin{array}{c}\text { Quezon } \\
\text { (6 respondents) }\end{array}$ \\
\hline Below 100,000 & 0 & 0 & 0 & 0 \\
\hline $101,000-120,000$ & 5 & 8 & 0 & 0 \\
\hline $121,000-130,000$ & 21 & 13 & 3 & 2 \\
\hline $131,000-140,000$ & 25 & 29 & 4 & 1 \\
\hline 141,000-Above & 129 & 51 & 7 & 3 \\
\hline
\end{tabular}

The normal condition farmers spend money on producing onion is ranging from 80,000 to 100,000 worth of inputs per hectare [10]. The table shows that 190 of the respondents spend 141,000 and above when it comes to the production of onion per hectare. It is common to have an average cost of
120,000 and above when pest is infesting the planted onions. They have accumulated greater cost during armyworm attack because according to the farmers interviewed the increase in the cost of producing onion during the armyworm infestation 
is due to the usage of expensive pesticides that farmers

believe to be effective against armyworm.

Table 5. Solutions applied by the farmers/Pest Control Methods Used for the Onion System in Bongabon, Rizal, Natividad and Quezon

\begin{tabular}{|l|c|c|c|c|}
\hline \multirow{2}{*}{ Pest Control Method } & \multicolumn{4}{|c|}{ Municipalities } \\
\cline { 2 - 5 } & $\begin{array}{c}\text { Bongabon } \\
\text { (180 respondents) }\end{array}$ & $\begin{array}{c}\text { Rizal } \\
\text { (110 respondents) }\end{array}$ & $\begin{array}{c}\text { Natividad } \\
\text { (14 respondents) }\end{array}$ & $\begin{array}{c}\text { Quezon } \\
\text { (6 respondents) }\end{array}$ \\
\hline Use of Pesticide & 175 & 110 & 14 & 6 \\
\hline $\begin{array}{l}\text { Field Monitoring/ } \\
\text { Plucking (pangunguto) }\end{array}$ & 4 & 0 & 0 & 0 \\
\hline $\begin{array}{l}\text { Cutting of Area Affected/ } \\
\text { pasusunog }\end{array}$ & 1 & 0 & 0 & 0 \\
\hline Water Treatment/ & 0 & 0 & 0 & 0 \\
\hline TOTAL & $\mathbf{1 8 0}$ & $\mathbf{1 1 0}$ & $\mathbf{1 4}$ & $\mathbf{6}$ \\
\hline
\end{tabular}

Table 5 shows that Spraying of pesticides during the armyworm infestation is the most commonly used method with 305 out of 310 respondents using this method. Field monitoring and some form of scouting were also used to check the types and densities of pests present. The table shows the proportion of farmers in each of the sites that practiced each of the pest control methods. In which the use of pesticides is the major solution when it comes to armyworm infestation. This is because most of the farmers use the type of pest management method that is easy to use such as pesticides. According to Serafin Santos, Provincial agriculturist he already discouraged farmers from using too much chemical and pesticides to save their crops from worms. "pangunguto" ( picking/plucking), removing armyworms by hand was one of the steps recommended by government agriculturists that are proven to be safe, less expensive and effective.
Table 6 shows that the 198 respondents from Bongabon, Rizal, Quezon and Natividad use Exalt as a pesticide. In their interview, most farmers from Bongabon stated that exalt has been the most effective pesticide among other brands as suggested by the other farmers. It was first available in Baguio and now it can also be bought in Bongabon. Although exalt is effective and does kill armyworm from the moment it is sprayed, the resurgence of the armyworm the other day still happens which causes them to spray almost on a daily basis. Exalt is also said to be an expensive brand that costs Php 2000 per bottle and adds up to the cost incurred when producing onion during an armyworm attack. The researcher includes the brand of pesticides often used by the farmers since it affects the amount of cost being incurred during armyworm infestation.

Table 6. Common Types of pesticides used by the Farmers to combat the pest

\begin{tabular}{|l|c|c|c|c|}
\hline \multirow{2}{*}{ Pesticide Used } & \multicolumn{4}{|c|}{ Municipalities } \\
\cline { 2 - 5 } & $\begin{array}{c}\text { Bongabon } \\
\text { (180 respondents) }\end{array}$ & $\begin{array}{c}\text { Rizal } \\
\text { (110 respondents) }\end{array}$ & $\begin{array}{c}\text { Natividad } \\
\text { (14 respondents) }\end{array}$ & $\begin{array}{c}\text { Quezon } \\
\text { (6 respondents) }\end{array}$ \\
\hline Brodan & 29 & 23 & 2 & 0 \\
\hline Atabron & 18 & 10 & 1 & 0 \\
\hline Exalt & 125 & 61 & 9 & 3 \\
\hline Lanette & 2 & 3 & 1 & 0 \\
\hline Others & 6 & 13 & 1 & $\mathbf{6}$ \\
\hline TOTAL & $\mathbf{1 8 0}$ & $\mathbf{1 1 0}$ & $\mathbf{1 4}$ & \\
\hline
\end{tabular}

\section{CONCLUSIONS AND RECOMMENDATIONS}

The effect of armyworms to the onion farmers generates great loss when it comes to the onion production and doubles up the cost in producing one due to the use of expensive pesticides. Farmers failed to generate 50 "buriki" bags of onion because of the infestation, they harvested only 15 bags 
of red onion bulbs. The Years 2014 and 2015 were not affected by armyworm, however, there are typhoons that hit some areas in Nueva Ecija which also cause to decline the onion production. Most of the farmer's knowledge of how armyworm should be treated is only limited and they opt to use pesticides that they think could treat the infestation. They focus on what they usually use rather than trying to learn other methods that are less expensive and environmentally friendly. As part of the recommendations, the researchers suggest that farmers should learn to adapt to other methods that the Department of Agriculture is introducing. Preventing the spread of armyworms through the use of natural and less expensive method must be the priority of each farmer. This is to help them lessen their cost as well as the damaged caused by the armyworms attack. The use of pesticides only adds up to the cost of production when armyworms are infesting. Farmers should also attend training and seminars provided by the Department of Agriculture in order for them to increase their analytical skills in situational settings [11] and to understand and gain more knowledge on when to start doing preventive measures during armyworms attack. Echoing of seminars on research on armyworms that is direct and simple [12] should also be considered and the DA should implement a more efficient system of communicating its research policies and programs down to the farmers' level [13] to enlighten the farmers about other methods of combating armyworms.

\section{REFERENCES}

[1] Onion.https://en.wikipedia.org/wiki/onion

[2] Cutworm'armyworm Infestation On Onion http://bpi.da.gov.ph/bpi/images/pdf_file/cutwormandarmywor m.pdf

[3] Worms Attack Filipino Onion Farms Source: Newsinfo.Inquirer.Net Publication Date: Thu 31 Mar 2016.https://businessmirror.com.ph/2019/03/21/fao-warnsagainst-extensive-use-of-pesticides-to-fight-

[4] Fao Warns Against Extensive Use Of Pesticides To Fight Fall Armyworm By Businessmirror -March 21, 2019201 https://businessmirror.com.ph/2019/03/21/fao-warns-againstextensive-use-of-pesticides-to-fight-fall-armyworm/

[5] Bonifacio F.Cayabyab. (May 2017).Public-private partnership in managing onion armyworm outbreak in Nueva Ecija. https://www.researchgate.net/lab/Bonifacio-F-Cayabyab-Lab

[6] Convenience Sampling https://researchmethodology.net/sampling-in-primary-datacollection/convenience-sampling/

[7] Red Creole Short Day Red Onion https://sakata.co.za/product/red-creole-short-day-red-onion/
[8] Jasper Y. Arcalas ( May 23, 20170). Government Sees Onion Supply Glut This Year businessmirror.com.ph

[9] Philippines - Onion-Growing City Loses P261m To Armyworms https://agroinsurance.com/en/philippines-onion-growing-cityloses-p261m-to-armyworms/

[10] Armand Galang - @ Inquirerdotnet Inquirer Central Luzon / 12:01 Am March 29, 2016

https://newsinfo.inquirer.net/776585/army-worms-attackonion-farms-in-ecija\#ixzz5orduqpme

[11] Subia, Gener S. (2018). Think Like My Teacher (TLMT): A New Method in Assessing Millennial Learners. International Journal of Arts, Humanities and Social Sciences. Volume 3. Issue 1.www.ijahss.com

[12] Subia, G. (2018) Comprehensible Technique in Solving Consecutive Number Problems in Algebra. Journal of Applied Mathematics and Physics, 6, 447-457. doi: 10.4236/jamp.2018.63041.

[13] Leila J. Abelardo, Mary Ann A. Lomboy, Cora C. Lopez, Felipe E.Balaria,Gener S.Subia (2019). Challenges Encountered by the National High School Teachers in Doing Action Research. International Journal of English, Literature and Social Science (IJELS) Vol-4, Issue-4, Jul - Aug 2019 https://dx.doi.org/10.22161/ijels.4418 ISSN: 2456-7620 